\title{
Efek Probiotik terhadap Mortalitas, Derajat Inflamasi Intestinal, dan Kadar IgA pada Mencit Model Sepsis
}

\author{
Yoseph Indrayanto, ${ }^{1}$ Diding Heri Prasetyo ${ }^{2,3}$ \\ ${ }^{1}$ Laboratorium Biologi Fakultas Kedokteran, Universitas Sebelas Maret Surakarta \\ ${ }^{2}$ Laboratorium Biokimia Fakultas Kedokteran, Universitas Sebelas Maret Surakarta \\ ${ }^{3}$ Divisi Imunologi, Laboratorium Biokimia Fakultas Kedokteran, Universitas Sebelas Maret Surakarta
}

\begin{abstract}
Abstrak
Sepsis mengubah mikrobiologi saluran pencernaan, menyebabkan hilangnyaflora komensal dan pertumbuhan bakteri patogen yang berlebih. Pemberian probiotik penderita sepsis dapat mengembalikan keseimbangan mikrobiota dan memiliki efek positif pada fungsi imunitas tubuh serta struktur dan fungsi gastrointestinal. Penelitian ini bertujuan untuk menentukan efek pemberian probiotik terhadap mortalitas, inflamasi intestinal, dan kadar imunoglobulin A (IgA) serum pada mencit model sepsis. Penelitian ini merupakan penelitian eksperimental laboratoris, dengan sampel 36 ekor mencit Balb/C jantan dibagi menjadi kelompok: kontrol, sepsis, dan sepsis+probiotik. Penelitian dilakukan di laboratorium Histologi dan Biomedik Fakultas Kedokteran Universitas Sebelas Maret Surakarta, periode Januari-April 2012. Mencit Balb/C jantan diinjeksi cecal inoculum (200 mg/kgBB) secara intraperitoneal (i.p), untuk kelompok sepsis maupun sepsis dengan probiotik. Kelompok mencit kontrol tidak diinokulasi selama penelitian. Inflamasi intestinal ditentukan dengan pengecatan hematoksilin eosin (HE) pada hari ke-8. Mortalitas dinilai sampai hari ke-8. Kadar IgA serum ditentukan menggunakan enzyme-linked immunosorbent assay. Twotailed Fisher Exact Test untuk uji mortalitas, Kruskal-Wallis untuk uji inflamasi intestinal, sedangkan analysis of variance untuk uji kadar IgA serum. Persentase kematian kelompok probiotik tidak berbeda bermakna (10\% vs $40 \%, p=0,065$ ) dibandingkan dengan kelompok sepsis. Probiotik bermakna menurunkan derajat inflamasi intestinal dibandingkan dengan kelompok sepsis $(\mathrm{p}<0,001)$. Kadar IgA serum kelompok mencit kontrol 35,82 $\pm 4,55 \mathrm{ng} / \mathrm{mL}$. Probiotik secara bermakna meningkatkan kadar IgA serum $(65,07 \pm 34,97 \mathrm{ng} / \mathrm{mL}$ vs $6,20 \pm 5,80 \mathrm{ng} / \mathrm{mL}, \mathrm{p}<0,001)$ dibandingkan dengan kelompok mencit sepsis. Simpulan, pemberian probiotik menurunkan derajat inflamasi intestinal dan mortalitas, serta meningkatkan kadar IgA serum pada mencit model sepsis. [MKB. 2013;45(1):10-5]
\end{abstract}

Kata kunci: IgA, inflamasi, probiotik, sepsis

\section{Probiotic Effects of Mortality, Degree of Intestinal Inflammation, and IgA Levels in Sepsis Mice Model}

\begin{abstract}
Sepsis results in changes to the microbiology of the gastrointestinal tract, leading to a loss of commensal flora and an overgrowth of potentially pathogenic bacteria. Administering probiotics to sepsis patients may restore balance to the microbiota and have positive effects on immune function and gastrointestinal structure and function. This study was aimed to evaluate the effect of probiotic on mortality, intestinal inflammation and immunoglobulin A (IgA) serum level in mice model of sepsis. This study was an experimental research laboratory, with 36 male $\mathrm{Balb} / \mathrm{C}$ mice were divided into: control, sepsis, and sepsis + probiotic groups. The study was conducted at Histology and Biomedical Laboratory, School of Medicine, Sebelas Maret University, Surakarta, in January to April 2012. Sepsis was induced in the male Balb/C mice using an intraperitoneally (i.p) injection of cecal inoculum (200 mg/ $\mathrm{kgBW}$ ), for sepsis mice model and sepsis with probiotic. Control mice were not inoculation during the study. Detection of intestinal inflammation with hematoxylin and eosin (HE) staining on 8th day. Mortality perceived until 8th day. IgA serum level measurement with enzyme-linked immunosorbent assay. Two-tailed Fisher exact test for the analysis of mortality, Kruskal-Wallis test for the intestinal inflammation, one way analysis of variance for IgA serum level. Probiotic showed no significantly mortality ( $10 \%$ vs $40 \%, p=0.065)$ compared to sepsis group. Probiotic showed significantly decreased intestinal inflammation compared to sepsis group $(\mathrm{p}<0.001)$. Control mice showed levels of IgA $35.82 \pm 4.55 \mathrm{ng} / \mathrm{mL}$. Probiotic showed significantly increased IgA levels $(65.07 \pm 34.97$ $\mathrm{ng} / \mathrm{mL}$ vs $6.20 \pm 5.80 \mathrm{ng} / \mathrm{mL}, \mathrm{p}<0.001)$ compared to sepsis group. In conclusions, probiotic decrease intestinal inflammation and mortality, on the other hand increase IgA level in mice model of sepsis. [MKB. 2013;45(1):10-5]
\end{abstract}

Key words: IgA, inflammation, probiotic, sepsis

Korespondensi: Diding Heri Prasetyo, dr., MSi, Lab. Biokimia Fakultas Kedokteran Universitas Sebelas Maret Surakarta. jalan IR Sutami 36A Kentingan Jebres Surakarta, mobile 081931671212, e-mail diding_hape@yahoo.co.id 


\section{Pendahuluan}

Sepsis ditandai oleh aktivasi yang saling tumpang tindih dan keterkaitan hormonal, inflamasi, dan kaskade imunologi yang mengarah pada inflamasi. Sistem pencernaan mempunyai peranan kunci dalam patogenesis multiple organ dysfunction syndrome (MODS) oleh karena gangguan fungsi sawar intestinal serta meningkatkan translokasi bakteri serta komponen bakteri ke dalam sirkulasi sistemik, mengakibatkan sepsis serta komplikasi infeksi sekunder sehingga kematiannya tinggi. Penyebab utama kematian penderita rawat inap di Intensive Care Unit (ICU) adalah systemic inflammatory response syndrome (SIRS), sepsis, dan MODS. ${ }^{1}$

Peran mikrobiota intestinal dalam inisiasi dan perjalanan penyakit kritis sudah semakin diakui dalam dekade terakhir. Beberapa penelitian yang telah dilakukan membuktikan pentingnya strain endogen bakteri probiotik seperti Bifidobacterium dan Lactobacillus dalam mempertahankan fungsi sawar intestinal serta memodulasi mukosa dan respons imun sistemik. ${ }^{2}$ Flora intestinal komensal memiliki peranan penting dalam metabolisme spesifik dan juga fungsi protektif. Keseimbangan antara spesies bakteri komensal akan memberikan kestabilan populasi mikrob pada individu dengan kondisi tidak normal. Selama periode sepsis berat, akan terjadi perubahan yang bermakna mikroflora intestinal diakibatkan beberapa faktor, termasuk perubahan hormon stres di dalam sirkulasi darah, iskemia intestinal, imunosupresi, dan penggunaan antibiotik, serta kekurangan nutrisi. Konsep terapi probiotik merupakan upaya untuk mengurangi atau menghilangkan semua mikrob patogen dan toksin, melepaskan nutrisi, antioksidan, faktor pertumbuhan dan faktor koagulasi, merangsang motilitas usus, serta memodulasi sistem imunitas bawaan dan adaptif melalui normalisasi flora usus yang berubah. ${ }^{3}$

Imunoglobulin A merupakan imunoglobulin utama yang ditemukan pada mukosa, sehingga disebut juga sebagai secretory immunoglobulin ( $\operatorname{sgA})$. Sekitar $80 \%$ total sel yang memproduksi imunoglobulin berada di dalam lamina propia usus. Enterosit termasuk tipe sel imunokompeten yang mempunyai peranan berbagai reaksi lokal terhadap mikroorganisme yang patogen. Interaksi enterosit dengan faktor-faktor di sekitarnya akan mengaktivasi ekspresi molekul adhesi, major histocompatibility complex (MHC) kelas I dan II, presentasi antigen terhadap limfosit, produksi sitokin, dan transportasi sIgA. Dengan hadirnya mikroorganisme probiotik akan memicu aktivasi sel imunokompeten, baik sel makrofag maupun sel dendrit sehingga gut-associated lymphoid tissues (GALT) yang ada pada lamina propia akan memicu sel plasma untuk memproduksi IgA yang berperan dalam sistem imun mukosa. ${ }^{4}$ Probiotik merupakan strain yang dapat meningkatkan fungsi imunitas tubuh dengan meningkatkan jumlah sel plasma yang memproduksi IgA, meningkatkan fagositosis, dan memengaruhi proporsi sel $\mathrm{T}$ helper 1 (Th1) dan natural killer (NK). ${ }^{5}$ Cara kerja probiotik tersebut dapat dimanfaatkan untuk mengatasi kondisi immunocompromised pada sepsis melalui jalur apoptosis terutama sel epitel gastrointestinal. Penelitian ini bertujuan untuk menentukan efek pemberian probiotik terhadap mortalitas, inflamasi intestinal, dan kadar IgA serum pada mencit model sepsis.

\section{Metode}

Penelitian ini merupakan penelitian eksperimental laboratoris, dengan sampel 36 ekor mencit Balb/C jantan dengan bobot badan $\pm 18-22$ gram dan berumur 4-6 minggu yang diperoleh dari Unit Pengembangan Hewan Percobaan Universitas Setia Budi, Surakarta. Bahan makanan mencit yang dipergunakan yaitu pakan mencit standar. Penentuan besar sampel dengan menggunakan rumus, ${ }^{6}$ yaitu:

$$
\begin{aligned}
& \text { Keterangan: }(\mathbf{t}-\mathbf{1})(\mathbf{n}-\mathbf{1})>\mathbf{1 5} \\
& \mathrm{t} \quad \text { banyaknya kelompok perlakuan } \\
& \mathrm{n} \quad \text { jumlah sampel per kelompok perlakuan }
\end{aligned}
$$

Dengan rumus tersebut akan didapat minimal sampel tiap kelompok sebanyak sembilan ekor mencit. Dalam penelitian ini kami menggunakan 12 ekor mencit untuk setiap kelompok karena tingkat mortalitas sepsis cukup tinggi.

Penelitian diselenggarakan di Laboratorium Histologi dan Biomedik Fakultas Kedokteran Universitas Sebelas Maret Surakarta, periode Januari-April 2012. Setelah semua hewan coba diadaptasikan selama seminggu, dibagi menjadi tiga kelompok masing-masing 9 (sembilan) ekor. Kelompok I tanpa perlakuan (sebagai kontrol), kelompok II adalah mencit model sepsis, dan juga kelompok III adalah mencit model sepsis yang diberi probiotik. Pada hari ke- 8 seluruh mencit dikorbankan untuk dikoleksi serumnya melalui pungsi jantung dan intestinal untuk menentukan derajat inflamasi.

Probiotik yang dipergunakan yaitu probiotik campuran dari B. longum, L. acidophillus, dan $B$. bifidum yang diproduksi Merck Tbk, dengan dosis $0,46 \mathrm{mg}$ tablet/mencit yang setara dengan pemberian satu tablet/hari pada manusia. Untuk membuat model sepsis, hewan coba diinokulasi dengan memakai cecal inoculum (200 mg/kg/ 


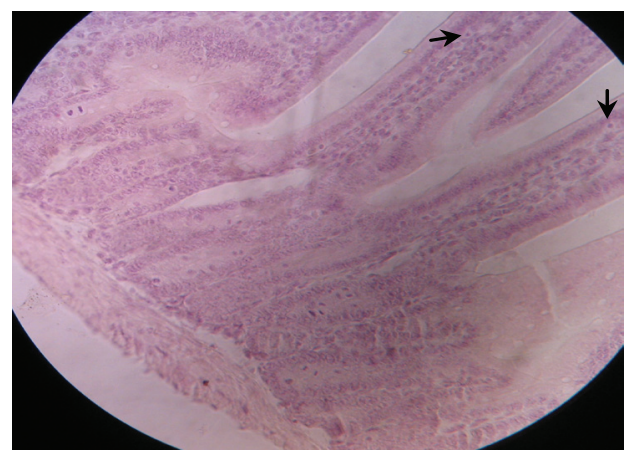

A

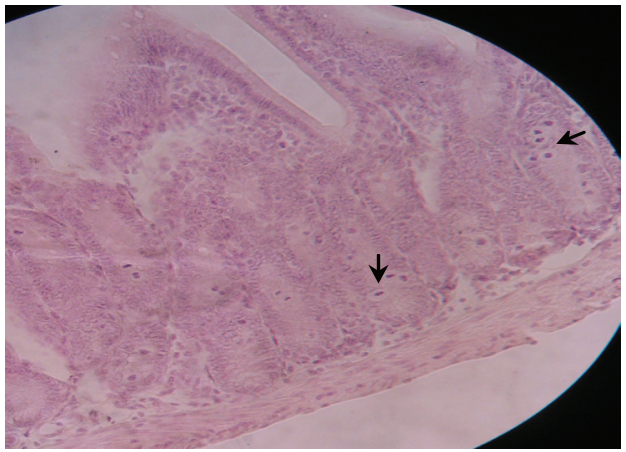

B

Gambar 1 Gambaran Histologi Intestinal Mencit Balb/C Pascapemaparan Cecal Inoculum menggunakan Pengecatan HE, dengan Pembesaran 400x. Infiltrasi sel radang ditunjukkan dengan anak panah. (a) Derajat 1 dan (b) Derajat 2

i.p.) dibuat baru setiap hari dari mencit donor yang dikorbankan dengan mensuspensikan 200 $\mathrm{mg}$ material cecal pada $5 \mathrm{~mL}$ dextrose water $5 \%$ (D5W) steril. ${ }^{7}$

Jaringan usus diambil sepanjang $1,5 \mathrm{~cm}$, kemudian direndam dalam larutan bufer formalin $10 \%$ selama 10 jam untuk dibuat blok parafin. Selanjutnya, dilakukan potongan serial untuk dibuat slide dan dilakukan pengecatan memakai HE untuk menilai gambaran histologi mukosa usus, selanjutnya diidentifikasi dengan mikroskop cahaya.

Menentukan derajat inflamasi mukosa usus dapat dilakukan berdasarkan modifikasi Geboes dkk., ${ }^{8}$ yaitu derajat $0=$ tidak ada infiltrasi sel radang (jaringan normal), derajat $1=$ infiltrasi sel radang sampai ke lapisan epitel mukosa usus, derajat $2=$ infiltrasi sel radang sampai ke lapisan epitel mukosa dan juga sedikit infiltrasi ke lapisan submukosa, derajat $3=$ infiltrasi sel radang sampai ke lapisan submukosa, dan derajat 4=infiltrasi sel radang sampai ke dalam lapisan muskularis atau transmural.

Penentuan kadar IgA serum dilakukan dengan enzyme-linked immunosorbent assay (ELISA) kit (GenWay Biotech, Inc.) sesuai dengan petunjuk dari pabriknya, sehingga akan didapatkan kadar IgA serum masing-masing kelompok.

Data yang diperoleh dianalisis dengan TwoTailed Fisher Exact Test, Uji Kruskall-Wallis maupun one way analysis of variance (ANOVA) dengan memakai program statistical package for the social sciences (SPSS).

\section{Hasil}

Setelah mendapat paparan cecal inoculum mencit dalam kelompok sepsis memperlihatkan tanda- tanda piloerection, periocular discharge, tampak lesu, penurunan nafsu makan maupun minum, dan diare. Keadaan tersebut lebih menonjol pada kelompok yang tanpa diberikan probiotik. Hasil penelitian memperlihatkan bahwa bobot badan sebelum dan sesudah perlakuan untuk kelompok sepsis terjadi penurunan secara bermakna $(22,1 \pm$ $1,1$ gram vs $20,2 \pm 1,7$ gram; $p<0,001)$, sebaliknya pada kelompok probiotik tidak menunjukkan penurunan berat badan yang bermakna $(24,8 \pm 2,4$ $\mathrm{g}$ vs $23,7 \pm 4,0 \mathrm{~g} ; \mathrm{p}=0,252)$.

Pada pengamatan survival ternyata $60 \%$ kelompok sepsis masih mampu bertahan hidup, sedangkan kelompok sepsis yang diberi probiotik yang masih bertahan hidup $90 \%(\mathrm{p}=0,065)$.

Gambaran histologis intestinal memperlihatkan berbagai derajat inflamasi yaitu kelompok kontrol sebanyak tiga sampel memperlihatkan gambaran histologis derajat 0 , enam sampel derajat 1, satu sampel derajat 2, dan dua sampel derajat 3 . Pemaparan cecal inoculum meningkatkan derajat inflamasi intestinal, hal ini terlihat pada kelompok sepsis yang memperlihatkan gambaran histologis pada delapan sampel dengan derajat 3 dan empat sampel dengan derajat 4. Pemberian probiotik pada mencit model sepsis terlihat menurunkan derajat inflamasi intestinal, sebanyak satu sampel memperlihatkan gambaran histologis derajat 1, enam sampel derajat 2, serta lima sampel derajat 3. Hasil Uji Kruskal-Wallis diperoleh $\mathrm{p}<0,001$, selanjutnya dilakukan post hoc test dengan Uji Mann-Whitney, yang masing-masing didapatkan hasil kelompok kontrol vs sepsis $(\mathrm{p}<0,001)$ dan sepsis vs sepsis + probiotik $(p=0,001)$.

Pemaparan cecal inoculum selama tujuh hari secara bermakna meningkatkan derajat inflamasi intestinal, pemberian probiotik secara bermakna menurunkan derajat inflamasi intestinal hewan 
Tabel 1 Sebaran Jumlah Derajat Inflamasi Intestinal

\begin{tabular}{cccc}
\hline $\begin{array}{c}\text { Derajat } \\
\text { inflamasi }\end{array}$ & Kontrol & Sepsis & $\begin{array}{c}\text { Sepsis }+ \\
\text { Probiotik }\end{array}$ \\
\hline 0 & 3 & - & - \\
1 & 6 & - & 1 \\
2 & 1 & - & 6 \\
3 & 2 & 8 & 5 \\
4 & - & 4 & - \\
\hline
\end{tabular}

coba model sepsis.

Penelitian ini memperlihatkan kadar IgA serum kelompok mencit normal yaitu 35,82 $\pm 4,55$ $\mathrm{ng} / \mathrm{mL}$. Pemaparan cecal inoculum dengan dosis $200 \mathrm{mg} / \mathrm{kgBB} /$ i.p. menurunkan kadar IgA serum secara bermakna $(p=0,002)$ menjadi $6,20 \pm 5,80$ $\mathrm{ng} / \mathrm{mL}$. Pemberian probiotik pada mencit model sepsis mampu meningkatkan kadar IgA serum secara bermakna $(p<0,001)$ menjadi $65,07 \pm 34,97$ $\mathrm{ng} / \mathrm{mL}$. Kadar terlihat melebihi kadar IgA serum mencit normal, meskipun peningkatannya secara statistik tidak berbeda bermakna $(p=0,078)$.

\section{Pembahasan}

Interaksi mikrob intestinal dengan isi luminal dan permukaan mukosa mempunyai peranan penting dalam perkembangan intestinal normal, nutrisi, dan imunitas. Intestinal memiliki luas permukaan besar serta area permukaan rapuh yang ditutupi oleh lapisan tipis sel-sel epitel multifungsi dan submukosa yang sangat imunoreaktif. Terjadinya gangguan sawar intestinal ini mungkin memiliki konsekuensi yang merugikan termasuk inflamasi sistemik, gangguan autoimun, dan alergi. Banyak bukti yang mendukung jaras brain-gut-intestinal microbiota, khususnya adalah sel epitel intestinal yang berfungsi sebagai mediator sinyal menuju sirkuit persarafan. Hal ini mempunyai arti penting dalam hal motilitas serta patofisiologi penyakit pencernaan akut dan kronik. ${ }^{9,10}$

Intestinal merupakan organ target penting bagi stres berat seperti sepsis, trauma, luka bakar, syok, perdarahan, dan infeksi. Stres berat terhadap intestinal dianggap mempunyai peranan penting dalam hal meningkatkan komplikasi infeksi dan MODS, sebagai gejala sisa interaksi antara epitel intestinal, sistem imun, dan bakteri komensal yang memburuk. Intestinal merupakan motor multiple organ failure (MOF), sekarang telah diakui bahwa disfungsi intestinal merupakan faktor penyebab dalam perkembangan penyakit. Flora intestinal serta lingkungannya secara bermakna mengalami perubahan pada penderita sakit berat, dan jumlah anaerob obligat dikaitkan dengan prognosisnya. Terapi sinbiotik merupakan kombinasi probiotik dengan prebiotik. Pemberian probiotik, prebiotik, serta sinbiotik telah dibuktikan sebagai terapi yang sangat menjanjikan untuk mempertahankan serta memperbaiki mikrobiota dan lingkungan intestinal. Pada penderita sakit berat, misalnya operasi besar abdomen, trauma serta penderita di ICU, terapi sinbiotik terbukti secara bermakna mengurangi kejadian sepsis. Penelitian dasar dan klinis lebih lanjut akan memperjelas mekanisme yang mendasari pengaruh terapi probiotik atau sinbiotik dan menentukan kondisi yang sesuai untuk digunakan. ${ }^{11}$

Permukaan sel-sel epitel intestinal selalu berhubungan dengan imunogen yang berpotensi merusak, baik yang berasal dari makanan, bakteri

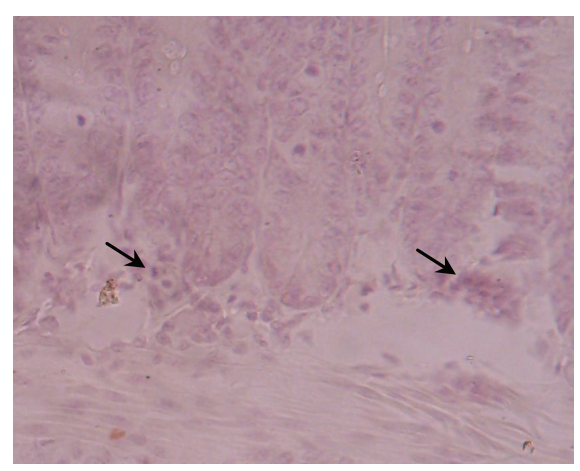

A

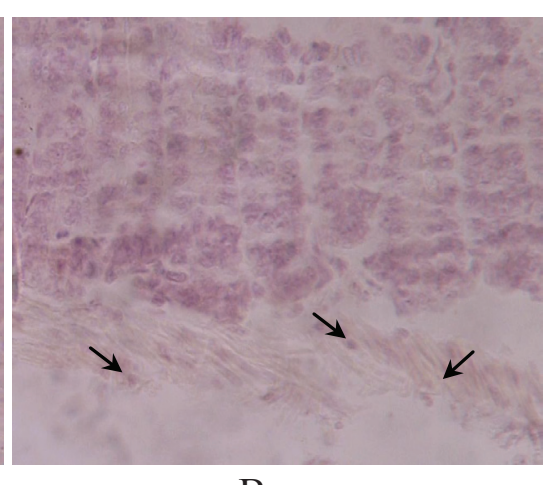

B

Gambar 2 Gambaran Histologi Intestinal Mencit Balb/C Pascapemaparan Cecal Inoculum Menggunakan Pengecatan HE dengan Pembesaran 1.000x. Infiltrasi Sel Radang Ditunjukkan dengan Anak Panah. (a) Derajat 3 dan (b) Derajat 4 
intestinal, ataupun mikroorganisme yang patogen. Untuk itu mukosa intestinal dilengkapi dengan ketahanan mukosa, baik alami maupun adaptif. Mekanisme pertahanan mukosa intestinal salah satunya melalui sekresi IgA, selain berbagai zat antimikrobial dan antiviral, seperti lisosom dan interferon. Integrasi dan keterpaduan berbagai komponen sistem pertahanan mukosa tersebut sangat diperlukan untuk dapat mempertahankan keutuhan fisiologis sistem saluran cerna makanan. Mikroflora yang bersifat melindungi mencegah invasi dan kolonisasi mikroorganisme patogen melalui IgA dan juga kompetisi terhadap reseptor dan atau substrat metabolik. ${ }^{4}$

Sel epitel saluran pencernaan berperan sebagai sel efektor imunologis dan juga mampu mengatur molekul permukaan dan menyekresikan sitokin serta kemokin untuk memfasilitasi presentasi antigen ke sel imun. Enterosit bertindak sebagai antigen presenting cell (APC) dan juga mengatur respons limfosit di intestinal. ${ }^{12}$ Perubahan fungsi intestinal sebagai penyebab berkembangnya sepsis ke arah kritis, sehingga intestinal dikenal sebagai motor respons inflamasi sistemik. Pada keadaan penyakit kritis, termasuk sepsis terjadi perubahan epithelial-commensal crosstalk yang meningkat. Pada SIRS berat atau sepsis, hiperpermeabilitas, supresi imun, serta pemakaian antibiotik akan mengubah keseimbangan mikroflora intestinal, yaitu jumlah bakteri yang menguntungkan, misal Bifidobacterium dan Lactobacillus lebih sedikit, sedangkan jumlah bakteri patogenik, misalnya Staphylococcus dan Pseudomonas lebih tinggi. ${ }^{13}$

Mukosa intestinal merupakan tempat utama pembentukan IgA. Masuknya antigen per oral akan merangsang pembentukan IgA. Menurut Sakr dkk. ${ }^{14}$ lipopolysaccharide (LPS) sebagai kompleks endotoksin glikoprotein dari komponen utama membran terluar bakteri gram negatif dapat menginduksi sepsis. Melalui mekanisme ikatan LPS-lipopolysaccharide-binding protein (LBP) yang akan menginduksi nuclear factor kappa $\mathrm{k}$ (NF-kB) sebagai sinyal pengatur transkripsi sitokin proinflamasi, kemokin, faktor koagulasi, serta molekul adhesi. Ekspresi NF-kB akan sangat memengaruhi prognosis sepsis, karena ekspresi yang berlebihan akan meningkatkan produksi sitokin proinflamatori yang akan meningkatkan apoptosis epitel saluran pencernaan.

Hal ini diperkuat oleh Chang dkk. ${ }^{15}$ bahwa proses patologik utama pada sepsis yaitu apoptosis sel efektor imunologi, termasuk sel limfosit dan dendrit maupun apoptosis saluran pencernaan. Dengan peningkatan apoptosis sel-sel efektor imunologi termasuk sel limfosit baik limfosit $\mathrm{T}$ maupun $\mathrm{B}$, dan sel dendrit yang berperan sebagai APC akan menurunkan produksi IgA. Hal ini sejalan dengan hasil penelitian, bahwa kelompok mencit sepsis akan mengalami penurunan kadar IgA serum dan peningkatan derajat inflamasi yang bermakna (Tabel 1). Hal ini akan mengakibatkan kerusakan barier intestinal. Penurunan sistem imun alamiah dan adaptif ini akan meningkatkan kematian hewan coba.

Pemberian probiotik merangsang terjadinya perkembangbiakan sel epitel dan meningkatkan pengembangan sistem imun sehingga ketahanan hidup kelompok mencit sepsis yang diberikan probiotik akan meningkat. Menurut Lomax dan Calder ${ }^{16}$ beberapa komponen sistem imun, seperti fagositosis, aktivitas sel NK, serta produksi IgA mukosa dapat ditingkatkan oleh beberapa bakteri probiotik. Hasil penelitian ini memperlihatkan bahwa pemberian probiotik dapat meningkatkan sekresi IgA secara bermakna dibandingkan dengan kelompok sepsis yang tidak diberikan probiotik. Hasil ini sejalan dengan penelitian Martino dkk., ${ }^{17}$ bahwa konsumsi formula yang mengandung probiotik (bifidobacteria) mampu meningkatkan konsentrasi IgA lokal sehingga dapat memberikan kontribusi peningkatan mukosa untuk melawan infeksi gastrointestinal. Hasil penelitian ini juga diperkuat hasil penelitian Alberda dkk. ${ }^{18}$ bahwa penderita yang mendapatkan probiotik kadar IgA dan IgG meningkat lebih besar secara bermakna dibandingkan dengan plasebo.

Pemberian probiotik pada hewan coba model sepsis akan meningkatkan konsentrasi IgA secara bermakna. Hal ini disebabkan oleh karena bakteri komensal (Bifidobacterium dan Lactobacillus) yang terdapat dalam probiotik diperlukan untuk perkembangan imunitas mukosa intestinal yang normal, dan juga akan mengendalikan inflamasi host-nya. ${ }^{19}$ Seperti halnya yang terlihat dari hasil penelitian ini, bahwa pemberian probiotik mampu menurunkan derajat inflamasi intestinal.

Sel dendrit akan mencapai lumen intestinal untuk dapat bereaksi dengan antigen maupun bakteri yang berada di dalam lumen intestinal. Meskipun penetrasi sel dendrit ke dalam lumen mukosa intestinal menembus sel epitel, integritas barier intestinal masih tetap terjaga, sebab sel dendrit mengekspresikan protein tight junction dan tetap memelihara keutuhan dengan epitel di sekitarnya. Sel dendrit tersebut akan mencerna sekaligus membawa bakteri komensal yang ada di lumen menuju nodus limfatikus mesenterikus, untuk selanjutnya akan menginduksi sekresi IgA, yang pada gilirannya akan melindungi intestinal dari penetrasi bakteri komensal lainnya. ${ }^{19}$ Selain itu, beberapa mekanisme aktivitas probiotik yang dapat menguntungkan yaitu kompetitif adherence bakteri, pelepasan bakteriosin untuk menghambat pertumbuhan patogen, efek antioksidan, stimulasi lendir dan produksi sIgA, peningkatan degradasi makromolekul yang mengurangi jumlah antigen, 
penekanan proliferasi sel imunitas, penghambatan aktivasi NF-kB sel epitel, modulasi apoptosis dan pemeliharaan sawar epitel, serta modulasi fungsi imunitas. ${ }^{2}$

Simpulan, pemberian probiotik secara oral meningkatkan sekresi IgA serum dan survival, serta menurunkan derajat inflamasi intestinal pada hewan coba model sepsis.

\section{Ucapan Terima Kasih}

Penulis mengucapkan terima kasih kepada Prof. Dr. A. Guntur H., dr., SpPD-KPTI, selaku Guru besar Ilmu Penyakit Dalam Fakultas Kedokteran Universitas Sebelas Maret Surakarta, atas ideide, saran, dan bimbingannya.

\section{Daftar Pustaka}

1. Alverdy JC, Laughlin RS, Wu L. Influence of the critically ill state on host-pathogen interactions within the intestine: gutderived sepsis redefined. Crit Care Med. 2003;31(2):598-607.

2. Morrow LE, Gogineni V, Malesker MA. Probiotic, prebiotic, and synbiotic use in critically ill patients. Curr Opin Crit Care. 2012;18(2):186-91.

3. Singhi SC, Baranwal A. Probiotic use in the critically ill. Indian J Pediatr. 2008;75(6):6217.

4. de Roock S, van Elk M, Hoekstra MO, Prakken BJ, Rijkers GT, de Kleer IM. Gut derived lactic acid bacteria induce strain specific CD4(+) $\mathrm{T}$ cell responses in human PBMC. Clin Nutr. 2011;30(6):845-51.

5. Bengmark S. Pro- and synbiotics to prevent sepsis in major surgery and severe emergencies. Nutrients. 2012;4(2):91-111.

6. Supranto J. Teknik sampling untuk survei dan eksperimen. Edisi ke-4. Jakarta: PT Rineka Cipta; 2007.

7. Chopra M, Das P, Golden H, Dostal DE, Watson LE, Sharma AC. Norepinephrine induces systolic failure and inhibits antiapoptotic genes in a polymicrobial septic rat model. Life Sci. 2010;18;87(23-26):6728.

8. Li CQ, Xie XJ, Yu T, Gu XM, Zuo XL, Zhou CJ, dkk. Classification of inflammation activity in ulcerative colitis by confocal laser endomicroscopy. Am J Gastroenterol. 2010;105(6):1391-6.
9. Jarchum I, Pamer EG. Regulation of innate and adaptive immunity by the commensal microbiota. Curr Opin Immunol. 2011;23(3):353-60.

10. Rhee SH, Pothoulakis C, Mayer EA. Principles and clinical implications of the brain-gut-enteric microbiota axis. Nat Rev Gastroenterol Hepatol. 2009;6(5):306-14.

11. Shimizu K, Ogura H, Goto M, Asahara T, Nomoto K, Morotomi M, dkk. Synbiotics decrease the incidence of septic complications in patients with severe SIRS: a preliminary report. Dig Dis Sci. 2009;54(5):1071-8.

12. Acheson DW, Luccioli S. Microbial-gut interactions in health and disease: mucosal immune responses. Best Pract Res Clin Gastroenterol. 2004;18(2):387-404.

13. Shimizu K, Ogura H, Goto M, Asahara T, Nomoto K, Morotomi M, dkk. Altered gut flora and environment in patients with severe SIRS. J Trauma. 2006;60(1):126-33.

14. Sakr Y, Burgett U, Nacul FE, Reinhart $\mathrm{K}$, Brunkhorst F. Lipopolysaccharide binding protein in a surgical intensive care unit: a marker of sepsis?. Crit Care Med. 2008;36(7):2014-22.

15. Chang KC, Unsinger J, Davis CG, Schwulst SJ, Muenzer JT, Strasser A, dkk. Multiple triggers of cell death in sepsis: death receptor and mitochondrial-mediated apoptosis. FASEB J. 2007;21(3):708-19.

16. Lomax AR, Calder PC. Probiotics, immune function, infection and inflammation: a review of the evidence from studies conducted in humans. Curr Pharm Des. 2009;15(13):1428-518.

17. Martino DJ, Currie H, Taylor A, Conway $\mathrm{P}$, Prescott SL. Relationship between early intestinal colonization, mucosal immunoglobulin A production and systemic immune development. Clin Exp Allergy. 2008;38(1):69-78.

18. Alberda C, Gramlich L, Meddings J, Field C, McCargar L, Kutsogiannis D, dkk. Effects of probiotic therapy in critically ill patients: a randomized, double-blind, placebo-controlled trial. Am J Clin Nutr. 2007;85(3):816-23.

19. Macpherson AJ, Uhr T. Induction of protective IgA by intestinal dendritic cells carrying commensal bacteria. Science. 2004;303(5664):1662-5. 